librarian of University of Redlands (Calif.) library.

Louis I. Іввотson, librarian of the University of Maine, Orono, retired on July 1 . He had been with the university for more than thirty years.

EDITH Jones retired on September 1 from her position as classics librarian at University of Illinois, Urbana, after thirty-four years with the library.

Richard S. MacCarteney, chief of the reference division of the copyright office at Library of Congress since 1947 retired in August.

Margaret Gayley Palmer retired as librarian of the dental school at University of Pennsylvania in June.

Warren L. Perry retired on September 1 after serving as librarian of the University of Puget Sound, Tacoma, Wash., for more than thirty years.

Abi Russell, who has been director of libraries at Alabama College, Montevallo, since 1931 , retired this autumn.

Veronica J. Sexton retired in August from the position she had held for thirty-three years, that of librarian of the California Academy of Sciences, San Francisco.

Mrs. Violet Shue retired on August 31 from the staff of the Hoover Institution at Stanford University. During most of the past forty-one years Mrs. Shue has served in various capacities in the libraries of Stanford, the Hoover Institution, and University of California, Santa Barbara.

Charles Holmes Stone, university librarian of Mercer University, Macon, Ga., retired on September 1.

\title{
Junior College Library Handbook Collection
}

A COLLECTION of student handbooks gathered from over fifty junior college libraries has been placed at ALA headquarters in Chicago. This collection is available on interlibrary loan to interested librarians or libraries.

The Committee on Instruction and Use, of the Junior College Library Section of ACRL, has made a study of student handbooks over the past two years. Initially, questionnaires concerning library instruction and the use of library handbooks were circulated to all junior college librarians in the United States. Handbooks were requested from the responding librarians.

Committee members then proceeded to study the handbooks themselves and to formulate standards for an "ideal" library handbook for junior college students. The standards dealing with format (size, reproduction techniques, etc.) and content (the card cata$\log$, circulation regulations, reference services) were compiled in June 1963 and made available at the ALA conference in Chicago.

At that time some of the handbooks, which were exceptionally well done, were displayed. Many librarians who visited the ACRL booth examined the handbooks, requested copies of the standards, and, in general, evidenced a genuine interest in the preparation and use of such library guides.

For those who were not able to see the handbooks at ALA, there is now opportunity to borrow them for more leisurely examination. Those that are especially recommended for comprehensiveness of coverage and distinguished format include those from Flint Community College, Foothill College, Los Angeles Harbor College, Los Angeles Valley College, Pasadena City College, Stephens College, and Wright Junior College.

However, the librarian who is revising a handbook, or preparing one for the first time, will find all of the handbooks very helpful.Alice B. Griffith, Chairman, Committee on Instruction and Use. 